\title{
CHRIST OUR LIGHT: THE EXPECTATION OF SEEING GOD IN CALVIN'S THEOLOGY OF THE CHRISTIAN LIFE
}

\author{
CARSTEN CARD-HYATT* \\ Leuphana Universität
}

\begin{abstract}
The beatific vision plays a prominent role in the history of Christian ethics. Reformed ethics has an ambiguous relationship to this history, on two counts. First, it offers some qualified critiques of the role of vision in ordering ethical understanding, and second, on some accounts, Reformed ethics shares some responsibility for the loss of transcendence in the modern world, and the narrowing of the ethical field that has resulted from this loss. This essay argues that the vision of God in John Calvin's understanding of the Christian life offers resources to defend a Reformed ethics from some recent detractors. Further, it provides a constructive contrast with the role of eschatology in a prominent strand of 20th century ethics. This argument is sustained through a close reading of Calvin's biblical commentaries on the role of theophanies and the promise of the vision of God, and of Book III, chapters 6-10 of the Institutes.
\end{abstract}

KEYWORDS: beatific vision, ethics, modernity, transcendence, Christian life, John Calvin

\section{Introduction}

The history of the phrase 'vision of God' is 'the history of Christian ethics itself', claimed Kenneth Kirk in his seminal 1928 Bampton lectures on the subject (Kirk 1991: 2). If this is so, it is difficult to say what role Protestant ethics plays in this history. Though pre-Reformation ethics hardly spoke with one voice, the prominence of the beatific vision as humanity's transcendent end encouraged (or perhaps entailed) an ethics that was intellectualist and eudaemonist- the fulfilment of human desire was to be had in the contemplation of the vision of God. We might then discern the effect of Protestantism when historians of ethics trace a broad shift in the early Modern period away from intellectualism and eudaimonism towards voluntarism and divine command theory (Schneewind 1998: 27-36, Irwin 2007:

* CARSTEN CARD-HYATT (PhD 2017, University of St Andrews) is a postdoctoral fellow at Leuphana Universität, Institut Ethik und Theologie in Lüneburg, Germany. Email: carsten.card-hyatt@leuphana.de. The author would like to thank Dr. Tim Baylor for assistance on this topic and the referees of Perichoresis for many helpful comments on the essay. 
744-45). However, the degree to which Protestant thought contributed to this shift is contested, if considered at all (O'Donovan 2012: 187). Nonetheless, Charles Taylor points to the decisive influence of Calvinist theology in shaping the modern moral self. This influence is not wholly malign: the Reformed 'affirmation of the ordinary life', as Taylor calls it, is a key part of the modern egalitarian project that is to be encouraged (Taylor 1989: 211 30). But this affirmation came as part of a rejection of a hierarchy between contemplative and active spiritual lives that led to narrowing of the transcendental horizon of human life and ultimately to the 'immanent frame' of secular individualism (Taylor 1989: 216, 2007, 2011:15-19). Without necessarily denying a transcendent end for humanity in the vision of God as such, Reformed theology, so the story goes, unpicks enough of the threads of pre-Reformation vision of human life fulfilled in God that the entire weave comes undone, leaving a very dubious legacy.

To assess this broad, yet influential history, more fine-grained analyses of the internal theological logic of Reformed ethical thought is needed, particularly in relation to such redoubtable pre-Reformation themes such as the vision of God (towards which Julie Canlis (2010) and Hans Boersma (2018) have recently made contributions). I aim to offer one such analysis in this essay by considering the critical yet central role John Calvin gives to the beatific vision in his theology of the Christian life. My argument is in three stages: first, Calvin's commentary on Old and New Testament theophanies show him considering the difference between faith's desire for the final vision and the present limits of human knowledge of God. Here Calvin makes his objections to the role sometimes played by the beatific vision in the life of faith clear, as he argues that the desire of faith to see God is not itself an unimpeachable guide to action. It may be that this desire reaches beyond the limits God himself has set for faith and so undermines its foundation. The primary critical move that Calvin makes is to argue that if the faith that is to be fulfilled in vision at the end of human life is to operate as it should in the present, it must be nourished and disciplined by the hearing of the Word of God in Scripture. This present dependence of faith on hearing God's Word leads to the second stage of my argument, which is the Christological focus of Calvin's understanding of the vision of God. Moving now from the commentaries to the Institutes, we will see how Calvin understands the faith in God revealed in Christ to be sustained in the hope of seeing the risen Christ unveiled in glory. This Christocentric account of the beatific vision brings an ineluctably Christological pattern to moral life in the present. It is for this reason that we will speak of Calvin's theology of the Christian life rather than his ethics, as his moral thought is not developed through a systematic treatment of virtue or duty, but of Christian action that adheres to the pattern of cruciform self-denial exhibited by Christ. Finally, 
we will see how faith in the revealed Christ oriented through hope towards the to be seen risen Christ allows for moral action by bringing forth moral freedom. We will be especially concerned in this section with the themes of self-denial and contempt for the world. These are especially pressing for contemporary concerns that any ethics which posits a transcendent end for humanity entails devaluing the genuine goods of this world, a point on which I aim to defend Calvin.

In general terms, then, I will argue that Calvin gives a role to the vision of God in his moral theology that is shaped by specifically Reformed concerns about the guidance of Scripture for faith and the centrality of the work of Christ. But I will also draw attention to how Calvin articulates the relation between faith and eschatological expectation in a way that is defendable against some modern criticisms and sets him apart from some more recent theology in a way that deserves consideration.

\section{'They could not find words': The Difficulty of Speaking}

\section{About the Beatific Vision}

Calvin's brief treatment of the beatific vision in the 1559 Institutes of the Christian Religion, is suggestive of several concerns about this topic evident elsewhere in his corpus, and his strategies for addressing them. It serves as our starting point for Calvin's handling of the topic.

What Calvin says directly about the beatific vision comes under the heading of the 'Final Resurrection', itself the culmination of the long argument of Book III for the sufficiency of God's grace in Christ. Referring generally to humanity's eternal happiness that is promised after the resurrection, the basic difficulty of the subject is that very little can be said with any firmness about the resurrected state, beyond its superlative joy. An implicit reference to 1 Corinthians 13:12 ('For now we see in a mirror dimly, but then face to face...' [ESV]) and quotation of 1 John 3:2 ('Beloved, we are God's children now, and what we will be has not yet appeared; but we know that when he appears we shall be like him, because we shall see him as he is' [ESV]) stand at the head of his reflections, and allow Calvin to affirm the beatific vision while drawing attention to its fundamental obscurity from the vantage of the present: 'Accordingly, the prophets, because they could not find words to express that spiritual blessedness in its own nature, merely sketched it in physical terms'(Calvin 1960: 1005). Calvin here affirms what the tradition before him also held: the human mind is quickly brought to its limits, spiritually and intellectually, when the task is to describe the beatific vision (Augustine 2015: 65). Yet where a figure such as Augustine found in confronting the limits of contemplating God the spur to further reflection and greater sanctity, Calvin sees a spiritual risk in overstepping the boundaries that God has set on present knowledge. The thrust of the biblical references 
to the final state of the redeemed is that 'every sort of happiness is included under this benefit' when the 'Lord will share his glory, power, and righteousness with the elect' (Calvin 1960: 1005). The richness and extravagance of the promised fulfilment of God's salvific work is to be savoured by the Christian, but it is precisely here that danger is concealed:

And although we have advanced considerably in this meditation, let us nevertheless acknowledge that, if our mental capacity be compared with the height of this mystery, we still remain at the very lowest roots... We also feel how we are titillated by an immoderate desire to know more than is lawful. From this, trifling and harmful questions repeatedly flow forth (Calvin 1960: 1005).

Calvin's language of lawful knowledge indicates that he does not consider the tension between the desire to see God and the present capacity to do so to be simply a matter of the frustration of proper desire, but that the desire itself may be misdirecting. This in itself is a key part of Calvin's understanding of the beatific vision in the Christian life, as he will undertake to show how the expectation of this vision may be disciplined in order to function properly. Yet Calvin's comments in the Institutes only sketch the lineaments of his argument and need filling out. Taking an interpretive cue from Richard Muller, who argues that Calvin always intended the Institutes to serve as a guide to his commentaries (2000: 101-17), we will turn to those to shed some light on our questions.

\section{Present Knowledge and Future Promise-The Beatific Vision in Calvin's Commentaries}

Our presiding concern in this section is to understand how Calvin conceives of the gap between faith's desire to see God and the present limits on the Christian's capacity to do so. As we have already seen, Calvin is worried that this gap will be a hindrance to the life of faith, not an encouragement to it. Why might this be so? And, most crucially for our purposes, does this exclude the desire for the beatific vision from having a positive role in Christian action?

Two categories of text will occupy us here. Calvin's comments on the verses directly relating to the beatific vision, passingly referenced in the Institutes, offer greater clarification on the positive role Calvin gives to the beatific vision in the Christian life. First, however, we will look at what Calvin has to say about two theophanic events, the passing of God before Moses on Mt. Sinai and Christ's transfiguration. Calvin treats both of these events as indicative of the general Christian relationship to the vision of God, where this relationship can go awry, and how it is to be ordered.

In both Moses's vision of God and the disciples' vision of Christ transfigured, Calvin draws attention to discontinuity between these events and the 
vision promised to the resurrected in Christ, a difference that Moses and the disciples fail to appreciate. Indeed, both Moses and the disciples are to be censured for overstepping their bounds in their desire to see God. Moses is 'carried beyond due bounds, and longs for more than is lawful or expedient' (Calvin 1852: 387) when he asks to see God's glory. Calvin notes that in Luke's account of the Transfiguration, Peter expresses his joy at the vision'Lord, it is good for us to be here'-while 'Moses and Elijah were departing'. 'Hence', says Calvin, 'we infer that he was afraid lest, at their departure, that pleasant and delightful exhibition should vanish away...But his desire was foolish' (Calvin 1845: 263). Calvin's judgment on both Moses and Peter seems brusque, considering the goodness of the object of their desire. 'We need not wonder', says Calvin, 'that Peter was so captivated by the loveliness of what he beheld, as to lose sight of every other person, and rest satisfied with the mere enjoyment of it' (Calvin 1845: 263). As for Moses, 'the desire itself was improper, though its object was correct' (Calvin 1852: 387). Why then, are they criticized?

What Moses and Peter both fail to recognise is the inherent limitations of their position this side of the resurrection. God reminds Moses that he would die should God grant his request, for to have a vision of God means, says Calvin, citing 1 John 3:2, to be 'like' God, that is, free of their present mortal bodies (Calvin 1852: 390). For his part, Peter fails to recognise the difference between his personal vision and the vision of God as the goal of redemption:

[Peter] foolishly dreamed that his present aspect, which was temporary, would endure for ever. And what if the kingdom of Christ had been confined in this way to the narrow limits of twenty or thirty feet? Where would have been the redemption of the whole world? Where would have been the communication of eternal salvation (Calvin 1845: 264)?

In both of these passages, Calvin draws on a fundamental connection between the resurrection, redemption, and the beatific vision, to which we will return in due course. But first, we can draw some preliminary conclusions from how Calvin handles both theophanies. It is important to Calvin that these theophanic visions must be understood within God's broader work of redemption, and the way he has chosen to reveal himself to humanity. This explains Calvin's elaboration from these visions to the common Christian response to revelation-as Moses and Peter must discipline their desire for vision to the terms of God's revelatory activity, so must all Christians. Such visions are not the rule, but the exception to God's communication to humanity, which is through his Word. It is, in fact, more important to Calvin that both Moses and the disciples at the Transfiguration are spoken to by God than that they enjoy some partial vision. In addition to promising to 
pass before Moses, God will 'declare the name of the Lord' before him. Calvin takes this to be the superior aspect of the theophany: 'A promise indeed is given that he shall behold God; but the latter blessing is more excellent, that God will proclaim this name, so that Moses may know Him more by His voice than by His face; for speechless visions would be cold and altogether evanescent, did they not borrow efficacy from words' (1852: 388). Calvin draws a similar point from the voice from heaven that speaks to the disciples, though with a more negative cast. The voice of God comes from a cloud, because vision tends toward idolatry. The voice of God, on the other hand, directs towards faith: 'Let us therefore endeavour by faith alone, and not by the eyes of flesh, into that inaccessible light in which God dwells' (1845: 265).

Two points by way of summary of what we have considered so far. First, where Calvin thinks the desire for vision can go wrong can be stated with more specificity: it is not only that the desire of Moses and Peter is overweening, it is that it presupposes a false continuity between the way faith knows God now and the way it will be fulfilled after the resurrection. The category of vision is not, therefore, sufficient to capture the ways in which God communicates to creatures, and an exclusive focus on the vision of God in the present will neglect the speech of God by his Word. Second, this disciplining of the desire for the vision of God by attending to the speech of God does not leave faith frustrated, but simply directed towards the present dispensation of God's redemptive activity.

Yet at this stage we might wonder if Calvin has overcorrected. It is clear how Calvin's at times censorious warnings against speculation derive from his conviction that having the right object of desire does not necessarily result in right action, and how an over-reliance on the category of vision can lead to the neglect of the full range of God's communicative activity. However, by pressing the discontinuity between the reliance of faith in the present on hearing and its ultimate fulfilment in vision (as affirmed in the Institutes), Calvin risks leaving the promised beatific vision without content, without force for life in the present. More simply, we might also protest that faith should desire the vision of God, and that the yearning for the vision of God is a well-established part of both Pauline and Johannine conceptions of the Christian life.

Calvin addresses both of these concerns in his comments on those verses that promise the eschatological vision of God, and which shape his treatment of the subject in the Institutes. When he comments on 1 Corinthians 13:12, Calvin makes it clear that any negative evaluation of present faith is comparative, not pejorative. In his gloss of speculum in aenigmate

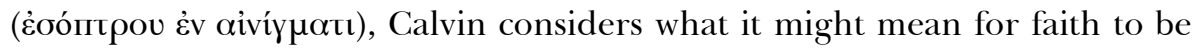
shrouded in obscurity. Faith, he says, 'at present beholds God as absent. 
How so? Because it sees not his face, but rests satisfied with the image in the mirror' (Calvin 1848: 367). This satisfaction with present faith is possible because of the ministry of the Word gives sufficient knowledge:

For we have in the word (in so far as is expedient for us) a naked and open revelation of God, and it has nothing intricate in it, to hold us in suspense, as wicked persons imagine; but how small a proportion does this bear to that vision, which we have in our eye! Hence it is only in a comparative sense, that it is termed $o b$ scure (Calvin 1848: 362).

By calling attention to the clarity of the knowledge of faith, along with its temporary status, Calvin seeks to keep the eschatological promise from undermining present faith (which it would do by holding us 'in suspense'), but also relates that faith to the promised future vision in such a way that the final end is not detached from it. This point is picked up in Calvin's comments on 1 John 3:2. Commenting on 'we know that when he shall appear', he glosses the knowledge of faith in relation to the eschatological appearance of Christ:

The word to know, shows the certainty of faith, in order to distinguish it from opinion. Neither simple nor universal knowledge is here intended, but that which every one ought to have for himself, so that he may feel assured that he will be sometime like Christ. Though, then, the manifestation of our glory is connected with the coming of Christ, yet our knowledge of this is well founded (Calvin 1855: 180).

Though Christ's 'glory' remains un-manifest (Calvin 1855: 180), a 'well founded' faith is not destabilised by the gap between the present and the awaited promise. The expectation of the future vision of God does not then create a tension within faith, but is rather the source of peace in the present. Calvin faults Augustine, who 'tormented himself' with 'refined questions' over how God can be seen. For 'we must beware, lest by wrangling... we lose that peace and holiness without which no one shall see him' (1855: 181).

Calvin's warning against an undisciplined desire for the vision of God in the present is thus a guard against an agonistic faith. This peaceful faith, faith that is not internally at odds with itself in the present, is on the one hand secured by focusing on the genuineness of faith's knowledge. The discontinuity between faith now and its fulfilment lies in the principle form in which faith receives knowledge, not in faith's lack of knowledge or in this knowledge being somehow defective. But, on the other hand, this conception of faith's satisfaction with God's Word in the present does not tell us how the awareness of the gap between faith's knowledge now can be salu- 
tary, how the direction of faith's gaze to its final fulfilment in the beatific vision can be fruitful for its present condition.

Calvin's answer to this question, and the foundation of his theology of the Christian life, is that these verses are to have a Christological reading. The 'he' who 'shall appear' is Christ, which Calvin bases on a crossreference with Colossians 3:3-4. The appearance of the resurrected Christ is the object of faith's hope. In this way, Calvin specifies the promise that 'we shall be like him' to mean being like Christ. This Christological reading allows Calvin to make an explicit moral connection between hope in faith's object and present existence: 'this hope will excite and stimulate us to follow purity, for it leads us straight to Christ, whom we know to be a perfect pattern of purity' (Calvin 1855: 181). Hope is the answer that can be given to faith's awareness that it is unfulfilled without introducing into faith doubts about its own sufficiency. Hope in Christ moreover orients the desire of faith to see God towards what God has already given of himself to be known: the incarnate Son. This Christological focus in turn is what directs faith to action, not action as such, but to a specific pattern of action determined by Christ's earthly life.

How Calvin develops this basic outline of the dynamic of faith and hope into a theology of the Christian life will occupy us in the remainder of this essay. But before doing so, I want to draw attention to Calvin's emphasis on the peace of present faith, and his resistance to allowing the awareness of faith's wait for eschatological fulfilment any sense of frustration or tension. We can contrast this pacific faith with some trends in 20th century Protestant ethics.

Protestant ethics in the last century has often looked to a productive tension in the Christian faith, both to create the space for action and to mark the difference between an evangelical ethics and the philosophically general variety (Wolfe 2013: 90-115). Kathryn Tanner notes that recent eschatologies have incorporated modernity's 'dissatisfaction with the achievements of past and present, and act according to the imperative of permanent revolution, in order to usher in the new' (Tanner 2005: 42-45). Though modern eschatologies tend to want to temper the revolutionary impulse, they derive moral energy from the dissatisfaction. A good example of this is Helmut Thielicke, who describes Christians as living in the 'tension' between the present and the coming aeons, 'Christian ethics is an impossible possibility' (Thielicke 1958: 75) which must exist within this presently irresolvable tension. There is thus a 'mystery' to ethics, which, besides being eschatological, is also Christological and 'sacramental' (Thielicke 1958: 76-77). The Christological mystery of ethics is related to the tension in the incarnation between Christ's divine and human nature. This does not mean Christ occupies a 'middle' between God and humanity as a 'demigod', but that due to 
the 'opaque' and 'hidden' miracle of the incarnation, there is an 'irresolvability' to the tension of Christian ethics: 'The How of action (Das Wie des Handelns) is hidden to the same degree as the How of the miracle of the incarnation and the Person of Christ is hidden' (Thielicke 1958: 76. See also O'Donovan 1986: 144-46). Moral action that arises from faith shares the same hiddenness as its object. Christian ethics, then, as it exists in this same tension is protected from being dissolved into an immanent project of moral betterment-from works righteousness. Moreover, this hiddenness keeps Christian moral action focused on the anticipation of God's judgment and his coming Kingdom. Yet, on this account, it is difficult to see how faith gains any intellectual purchase on the character of the actions which are to arise from it. If faith is not to be removed from deliberative action in the present, then faith must be able to confidently say that the relationship between the knowledge it possesses now and what will be revealed then is not wholly shrouded in mystery. For Thielicke, the tension inherent in eschatological expectation comes to determine the character of faith's perception. Put differently, the anticipatory character of hope has become overly determinate for faith. We have already seen Calvin's suspicion of a faith too confident in its capacity for vision in the present, but it is important to see how one might go beyond the chastening that Calvin desires. The sort of tension that Thielicke describes would by Calvin's lights not only misunderstand the nature of faith, but also could not lead to the kind of moral agent Calvin thinks the Christian should be.

What kind of moral agent this is, and how one becomes one, is the theme of the next two sections.

\section{Self-Denial, the Vanity of the World, and the Expectation of Redemption}

In the first section, we gained a fuller picture of Calvin's understanding of the beatific vision and its relationship to faith through his biblical commentaries. The task now is to see how this picture might illumine Calvin's account of the Christian life found in the Institutes. The passage that runs from chapters 6 to 10 of Book III does not exhaust Calvin's moral theology, but it does include the core of what he has to say about the shape of human life lived sub specie Christi. It must be said that the role of the beatific vision is somewhat in the background in the initial stages of Calvin's theology of the Christian life. Nevertheless, they are important for us here because, first, it is necessary to see how the Christological pattern of the Christian life culminates in the vision of God in Christ, and second, the characteristics of the life explicitly lived in hope of this vision follow from Calvin's account of the Christian life generally.

At the end of the previous section, we noted how some trends in $20^{\text {th }}$ century Christian ethics have looked to the apparently inherent tension be- 
tween the present and the expectation of eschatological fulfilment as a site productive of Christian moral action. We also saw how Calvin explicitly resists internalising such a tension to faith. Yet the faith directed by hope to the returning Christ cannot but be aware its present lack of fulfilment. How does this awareness determine Christian action?

As alluded to in the introduction, it is best to think of Calvin's moral thought in the portion of the Institutes under discussion as a theology of the Christian life, because it advances in stages of moral reflection that correspond to rebirth and awareness of sin, through stages of moral growth towards those virtues associated with a life lived in full expectation of seeing God in Christ. If we are to understand this pattern of the Christian life (though Calvin does not imply it is simply one of linear progress), we must begin with the moral condition of humanity without Christ.

For Calvin, helplessness is the postlapsarian state of human life. It is this effect of sin, for which humans are culpable, that governs their moral reality. The universality of sin is thus not simply a means of securing universal culpability before God, but of setting the ethical helplessness of humanity in its proper moral-theological context. Humanity is helpless to do what it ought, to properly pursue the good, as well as being helpless before its own ignorance and vanity. Put differently, humanity lacks both freedom 'from' the predations of their and others' sin and freedom 'to' live righteously (See Berlin 1969: 118-72). Because this moral helplessness is not essential to humanity, but accidental (Calvin 1960: 246-48), Calvin sees the moral life in terms of responsibility lost, and so we might think of the present condition as humanity helpless before its own responsibility: humanity is 'hedged about on all sides by most miserable necessity' but nonetheless one should 'be instructed to aspire to a good of which he is empty, to a freedom of which he has been deprived' (Calvin 1960: 255).

The necessary starting point of the moral life is grace, therefore, because what is required is the renewal of her agency. Yet this renewal of agency in Christ does not realise itself in following certain patterns of conduct, but requires further instruction in order to correctly perceive its nature. The contrast here is with the law, which while it provides an ordinate pattern of human conduct, nonetheless 'it seemed good to the Heavenly Teacher to shape his people by an even more explicit plan' (Calvin 1960: 689).

The necessity of instruction is significant for at least two reasons. The first is that it means the pattern of life to which grace summons and enables the agent is not generic, but theologically specific. The 'explicit plan' that Calvin has in mind is following the pattern of Christ's life, which Calvin develops in terms of self-denial, denial of the world, and living in expectation of the future resurrection and vision of God. The second is that the negative aspects of Calvin's moral theology-Calvin's rather pungent rhetoric 
about self-denial and the vanity of the world can be found on most pages of Book III.7-are not principles of action that flow naturally from an end eschatologically conceived, but rather are made possible through the guidance of the Spirit (Calvin 1960: 690). It is important to register that Calvin does not depict the business of the 'renewal of the mind' as simply the task of repudiating present existence. It may seem that while Calvin denies that faith is in suspense due to its anticipation of being fulfilled in resurrected vision, he has instead located the eschatological tension entirely between the Christian and the present world. The renewal of agency directed towards seeing God in Christ would then create a dualism between the present and the eschatological future, which must consider the present as a weight to be thrown off. It would be a mistake to attribute this position to Calvin. Though while Calvin's affirmation of goods for use in creation (Calvin 1960: 714-15) or the permissible enjoyment of aesthetic and physical pleasures (Calvin 1960: 719-22) should not be ignored in this regard, the most important factor is Christological. Because the Christian is to take on the pattern of Christ's life through knowing Christ in faith, and so becoming like him, Calvin envisions a renewal of agency in and for the present world even as Christ's was and is.

Self-denial, then, is properly understood as bearing one's own cross. This brings the broad notion of self-denial to bear on a specific history, Christ's, whose life offers pattern of action in which a human life can share. Yet, for Calvin Christ is not simply 'the paradigm of human suffering and sacrifice' (Nussbaum 1990: 375-76). Rather, that which the Christian can know of Christ in their present is directed towards and transformed by that which is promised them:

we share Christ's sufferings in order that as he passed from a labyrinth of all evils into heavenly glory, we may in like manner be led through various tribulations to the same glory...when we come to know the sharing of his sufferings, we at the same time grasp the power of his resurrection; and when we become like him in his death, we are thus made ready to share his glorious resurrection (Calvin 1960: 702).

We see here the same dynamic at work which we saw in Calvin's commentary on 1 John: the knowledge of God in Christ available in the present is directed towards the end of being with God. And so the Christological pattern of the Christian life culminates for Calvin in the meditation on the future life. The 'future life' is something of a catch all term for Calvin, though the repeated emphasis is on finally seeing Christ in glory, or the beatific vision with a Christological focus. It is also in this section where Calvin articulates the full renewal of agency made possible for the Christian, and how 
this meditation on the future life marked by the possession of the particular virtue of patience. It is to this material that we now turn.

\section{The Meditation on the Future Life and Christ's Example of Patience}

We have repeatedly drawn attention to Calvin's understanding of the Christian faith as peaceful, without suspense, even as he argues that such faith should also be directed in hope to the final appearing of God as its fulfilment. This is appears paradoxical, as the Christian should be drawn towards an unrealised future yet be untroubled by its lack of appearance. In the last section we noted how the condition of sin provides one source of tension, though we further argued that the denial of self and world should not be taken as a repudiation of the present world tout court. Despite this caveat, the culmination of Calvin's picture of the Christian life as the meditation on the future does press a further question: will not an agency renewed in the context of looking beyond the present world struggle to find a place in it?

The foregoing concern can be considered part of a general suspicion of the role of transcendent ends in ethics. It will be helpful to expand on this suspicion now. The basic charge is that a morality that is ordered towards the transcendent runs the risk of ceasing to be a human morality. By making a standard of goodness, or the good itself, that sits beyond the frame of human existence the goal of action, such a morality may demand a rigour that fails to be responsive to the limitations that circumscribe human lives and attachments, and so fail to be ethically meaningful (Nussbaum 1990: 365-91). Not only may such an ethic fail to possess the descriptive and analytical resources necessary to respond to the full range of possible human goods, it may require the repudiation, or at least the diminishment, of some of those goods. There is inevitably a negative side to a positive transcendence, which demands the denial of this worldly goods in favour of the goods of the world to come. Criticisms of this sort from both within and without Christian theology are widespread. For one example of an intramural critique, Colin Gunton's (1993: 41-73) attack on the Platonic/Augustinian influence in Christian theology could easily include Calvin, though he is not Gunton's focus. Gunton claims that Western theology's failure to possess an adequate doctrine of creation and its concomitant focus on a transcendent, otherworldly future, means that it cannot respond with ethical appropriateness to the particularity of the present world.

For those looking to make such a critique, Calvin seems to provide a broad target. This is especially so as Calvin's commendation of meditation on the future life marks a shift in emphasis from the earlier discussion of self-denial to the ephemerality of this world and patience in the face of suffering. This transition takes place during the passages on bearing one's 
cross, wherein Calvin suggests that the effect of the moral life in the light of the cross is to be trained to yearn for the new world and the life to come. Thus, Book III.9, on the meditation on the future life, begins with a discussion of the vanity of the world that corresponds to the previous call to selfdenial, and concludes with an encouragement to yearn for the comforts of heaven (Calvin 1960: 712-14, 718-19).

Further, it is here, where all forms of the denial of sin in the present is brought under the expectation of seeing God in Christ, that Calvin sees moral agency renewed. For those that fully inhabit the expectation of the resurrection now, the result is that 'in their hearts the cross of Christ will at last triumph over the devil, flesh, sin, and wicked men' (Calvin 1960: 719). Precisely directed against the sources of humanity's moral helplessness, the Christian may now fully enter into life in freedom. But in a world wherein in $\sin$ is so pervasive, how will this freedom be any different from detachment? Calvin directly addresses this question by arguing that the Christian thus freed will share in Christ's patience, which he showed 'us an example of... in himself' (Calvin 1960: 702).

Patience for Calvin marks the character of the Christian who lives in hope of seeing God. He contrasts patience with the apathy of the Stoics (Calvin 1960: 708-12). Calvin's rejection of Stoic apathy is grounded in the by now familiar Christological basis: If weeping and groaning, or sadness and care, are to be judged unworthy, then, Calvin points out, so Christ's behaviour is also unworthy. The clear scriptural accounts of Christ's demonstrative sorrow are inescapable. Yet the inescapability of sorrow is not simply a submission to it, but rather a summons to patience. With patience, Calvin seeks to articulate a moral position beyond an insensibility to suffering and a total helplessness before it. It is instructive that to attempt to be insensible to suffering is to attempt to deny one's own nature: 'For the adversities themselves will have their own bitterness to gnaw at us... thus we shall be smitten by the pain of disgrace, contempt, injustice; thus at the funerals of our dear ones we shall weep the tears that are owed to our nature' (Calvin 1960: 710). Pace Gunton, Calvin seeks precisely to give the particularity of creation its due in light of the eventual appearing of God in Christ. Here, Calvin suggests that proper meditation on the future life manifests itself as confidence in God's providence in the present. This confidence is not to be confused with a philosophical submission to necessity because it arises out of the renewed moral freedom. Again, in contrast to apathy, patience is active and participatory, for 'if we obey God only because it is necessary, if we should be allowed to escape, we will cease to obey him', but 'we do not yield to necessity but we consent to our own good' (Calvin 1960: 711-12).

The meditation on the future life has come full circle back to the present condition of humanity. This is now altered by its relation to the coming of 
Christ in glory. It is precisely the hope for this vision that makes the relation to the present that Calvin calls patience possible. What will be seen allows what is seen to be in Christ. Finally, however, this is not merely a change in perception, but part of a capacity to be active in the present with freedom.

\section{Conclusion}

In this essay, I have offered a high-level reading of Calvin's theology of the Christian life, with a view to how his critical use of the vision of God plays a role in account of Christian moral existence and agency. Calvin's concern that the desire of faith for vision will undermine its role in the present gives way to a Christologically patterned moral life in which hope for the final vision sustains faith in confident freedom towards the present. In closing, I want to draw attention to two elements of what we have surveyed that seem especially noteworthy.

First, at the beginning of the essay, I drew attention to Charles Taylor's account of the modern self, and the role Reformed thought might have played in bringing it about. While this essay is not intended as a corrective to Taylor, we have seen how much Calvin is aware of the risks of either letting the promised future occlude the demands of the present, or overstating the possibilities in the present for grasping the desired transcendent end. Calvin's way of resisting both alternatives, I have argued, is consistently Christological. It is of course this element that is the hardest to generalise; the most difficult to integrate into a secular ethic. It may be that the most pressing question for assessing the legacy of Reformed ethics will be to ask if and where this Christocentrism was lost. Especially when asking how the beatific vision might play a more prominent role in contemporary Reformed thought, Calvin's Christological focus ought to be significant.

Secondly, Calvin's emphasis on the confident knowledge of faith is noteworthy. Central to his criticism of the way that faith's desire for a final vision can be morally damaging is that this desire may undermine and misdirect it. Though Calvin looked back to Augustine for this tendency, as we saw previously in the 20th century there has also been a desire to trouble faith's confidence. This has been notably so in relationship to faith's expectation of eschatological fulfilment. Such eschatological expectation suffers in the present from a bad conscience, the source of which is best described by Nietzsche. He drew attention to the apparent irony and implicit agenda in eschatological hope, wherein the apparent repudiation of the present world for the sake of the next is covertly a powerful source for re-describing and controlling present moral action (Nietzsche 1969: 213-14). One way of responding to this charge has been to make the eschatological expectation a source for the critique of faith, as well as the world in general. There can be no secret triumphalism if faith is disturbed in equal measure with other pre- 
sent realities. Yet we have seen that part of the moral strength of Calvin's position is precisely the clarity of faith's knowledge in its expectation, and the confidence in the present which that engenders. We have argued that this confidence is crucial for preventing the pattern of Christ's self-denial and repudiation of the world turning into self-sustaining principles of rejection and detachment. As such, when Christ is seen, and the awaited triumph at last arrives, it will necessarily be Christ's triumph, all of which means there need not be any anxious uncertainty about a life lived out of a faith so disciplined but, as Barth would later put it, such a life may claim 'assured and patient and cheerful expectation' (Barth 1961: 909).

\section{Bibliography}

Augustine (2015) De trinitate. Trans. Hill, Edmund. Hyde Park, NY: New City Press.

Barth K (1961) Church Dogmatics. Vol. IV/3.1.Edinburgh: T\&T Clark.

Berlin I (1969) 'Two Concepts of Liberty'. In: Four Essays on Liberty. Oxford: Oxford University Press.

Boersma H (2018) Seeing God: The Beatific Vision in Christian Tradition. Grand Rapids, MI: Wm. B. Eerdmans Publishing Co.

Calvin J (1845) Harmony of the Evangelists, Matthew, Mark, and Luke. Vol. II. Trans. Pringle W. Grand Rapids, MI: Christian Classics Ethereal Library.

Calvin J (1848) Commentary on the Corinthians. Vol. I. Trans. Pringle J. Grand Rapids, MI: Christian Classics Ethereal Library.

Calvin J (1852) Harmony of the Law. Vol. III. Trans. Bingham CW. Grand Rapids, MI: Christian Classics Ethereal Library.

Calvin J (1855) Commentary on the Catholic Epistles. Trans. Owen J. Grand Rapids, MI: Christian Classics Ethereal Library.

Calvin J (1960) Institutes of the Christian Religion (1559). Trans. Battles F L. Louisville: Westminster John Knox Press.

Canlis J (2010) Calvin's Ladder: A Spiritual Theology of Ascent and Ascension. Grand Rapids, MI: Wm. B. Eerdmans Publishing Co.

Gunton C (1993) The One, The Three and The Many: Creation and the Culture of Modernity. Cambridge: Cambridge University Press.

Irwin TH (2007) The Development of Ethics Volume 1: From Socrates to the Reformation. Oxford: Oxford University Press.

Kirk K (1991) The Vision of God. Cambridge: James Clark \&Co.

Nietzsche F (1969) Nietzsche Werke. Vol. 3. Berlin: Walter de Gruyter.

Tanner K (2005) Eschatology and Ethics. In: The Oxford Handbook of Theological Ethics. Oxford: Oxford University Press.

Taylor C (1989) Sources of the Self: The Making of the Modern Identity. Cambridge: Cambridge University Press. 
Taylor C (2007) A Secular Age. Cambridge, Mass.; London: Belknap Press

Taylor C (2011) Iris Murdoch and Moral Philosophy. In: Dilemmas and Connections: Selected Essays. Cambridge, MA: London: Belknap Press.

Thielicke H (1958) Theologische Ethik. Vol. I. Tübingen: JCB Mohr (Paul Siebeck).

Muller R (2000) The Unaccommodated Calvin. New York, Oxford: Oxford University Press.

Nussbaum M (1990) Transcending Humanity. In Love's Knowledge: Essays on Philosophy and Literature. Oxford: Oxford University Press.

O'Donovan O (1986) Resurrection and Moral Order: An outline for evangelical ethics. Leicester, England/Grand Rapids, MI: Inter-Varsity Press/William B. Eerdmans.

O'Donovan O (2012) The Future of Theological Ethics. Studies in Christian Ethics 25(2): 186-198.

Schneewind J B (1998) The Invention of Autonomy: A History of Modern Moral Philosophy. Cambridge: Cambridge University Press.

Wolfe J (2013) Heidegger's Eschatology: Theological Horizons in Martin Heidegger's Early Work. Oxford: Oxford University Press. 